\title{
LEF1 wt Allele
}

National Cancer Institute

\section{Source}

National Cancer Institute. LEF1 wt Allele. NCI Thesaurus. Code C80033.

Human LEF1 wild-type allele is located within 4q23-q25 and is approximately $121 \mathrm{~kb}$ in length. This allele, which encodes lymphoid enhancer-binding factor 1 protein, is involved in the mediation of both transcription and signal transduction. Genetic variation may be associated with both the occurrence and relapse of acute lymphoblastic leukemia. 